\title{
The Regional Effects of Monetary Policy in Europe
}

\author{
Ivo J.M. Arnold \\ Universiteit Nyenrode
}

\begin{abstract}
Since the inception of EMU, a common concern is that European monetary policy may have differential effects on EMU member countries. However, the reliance on cross-country evidence in the empirical literature risks overemphasizing the importance of cross-country differences in monetary transmission. This paper therefore takes a regional approach. Data from 58 European regions show significant cross-regional differences in the effects of monetary policy within the five largest EU countries. For all regions combined, I find a significant relationship between the impact of monetary policy and the industrial composition of regions, supporting earlier findings for the US. I conclude that at present the large European countries are regionally well-diversified enough to minimize the risk that ECB policy will produce a markedly different impact across countries.

- JEL Classification: E50

- Key Words: Monetary Transmission, Regional Effects, EMU
\end{abstract}

\section{Introduction}

Before Economic and Monetary Union (EMU) came into being, a major economic debate concerned the costs and benefits of monetary unification. Regarding costs, the absence or presence of asymmetric shocks became a wellresearched issue, see OECD (1999). A broad consensus on whether asymmetric shocks constitute a major impediment to monetary union has, however, failed to emerge. Bayoumi and Eichengreen (1993) exemplify the pessimistic view that the presence of asymmetric shocks will entail severe costs, while Bini Smaghi and

\footnotetext{
*Corresponding address: Ivo J.M. Arnold, Universiteit Nyenrode, Straatweg 253621 BG Breukelen, The Netherlands. Tel.: +31-346291270, Fax.: +31-346291250, E-mail: I.Arnold@nyenrode.nl. (C)2001-Center for International Economics, Sejong Institution, All Rights Reserved.
} 
Vori (1993) represent a more optimistic viewpoint.

Now that EMU has become reality, attention has shifted away from asymmetric shocks towards the asymmetric transmission of uniform monetary policy shocks originating from the European Central Bank (ECB). The concern is that a common monetary policy might have differential effects on EMU member states, caused by differences in the monetary transmission mechanism. When one size doesn't fit all, this may complicate macro-economic management, as the ECB will have to weigh the varying consequences of its actions on EMU countries. More importantly, when ECB policy is seen to be incapable of addressing the economic needs of individual member states, this might erode political and public support for monetary union. For the ECB, it is therefore important to understand how interest rates affect the euro area and what it can do to mitigate any differential effects.

The literature dealing with monetary transmission in the euro area is surveyed in Favero and Giavazzi (1999), OECD (1999), De Grauwe (2000) and Eijffinger and De Haan (2000). Most empirical studies report differences in the monetary transmission across European countries, but a consensus on the ordering of countries according to the interest rate responsiveness of GDP is lacking. This could be attributed to the diversity in econometric methodologies which have been employed. For example, BIS (1995), Hughes Hallett and Piscitelli (1999) and Hughes Hallett, Piscitelli and Warmedinger (2000) use existing large-scale macroeconomic (single or multi-country) models; Brittan and Whitley (1997) employ a small structural macromodel; Dornbusch, Favero and Giavazzi (1998) use reduced-form equations and Gerlach and Smets (1995), Barran, Coudert and Mojon (1997), Ramaswamy and Sloek (1997) and Ehrmann (1998) use structural vector autoregression models. In addition to the above-mentioned differences in ordering, Kieler and Saarenheimo (1998) question the statistical significance of the reported cross-country differences.

Empirical studies documenting differences in monetary transmission across European countries typically use country data. Exceptions are Ganley and Salmon (1997) and Hayo and Uhlenbrock (2000), who explore regional differences in monetary transmission within respectively the UK and Germany. Carlino and DeFina (2000) apply estimates from regional US data to the EMU. But these studies do not provide a comparison across multi-national EU regions. In contrast, the literature on asymmetric shocks includes regional EU evidence, see De Grauwe and Vanhaverbeke (1991) and De Nardis, Goglio and Malgarini (1996). 
One of their findings is that the variability of output is much greater at the regional than at the national level. In that case, regional diversification within EU countries would mitigate the potential instability arising from asymmetric shocks.

The focus of much of the empirical literature on cross-country differences in monetary transmission is understandable. The lack of political integration in Europe implies that the nation state is still a force to be reckoned with. As discussed above, wide cross-country differences in the impact of monetary policy shocks may have political repercussions. Yet, solely relying on cross-country evidence carries the risk of overstating the importance of cross-country differences. Comparing these to regional differences within countries may put them in a different perspective. Suppose, for example, that some EMU countries have experienced a wide regional variation in the transmission of their monetary policy before EMU. This finding could result in a more balanced appraisal of the importance of cross-country differences in the EMU. A comparison of regional and national variation therefore makes sense in analyzing the transmission of ECB policy to the euro area.

This paper measures the impact of monetary policy shocks on regional GDP using data from 58 European regions. The estimates will be used to address three questions. First, I will examine regional variation in monetary transmission within EU countries. Next, I try to explain the regional effects of monetary policy. Building on the work of Carlino and DeFina (1998), I look whether the impact of monetary policy shocks is related to the industrial composition of regions. In addition, dummy variables are used to control for possible country factors. Third, I test whether the differential effects of monetary policy vary more within countries or between countries.

The organization of this paper is as follows. The next section offers a brief review of factors which may cause differential effects of monetary policy. Section III is the main part of this paper. It includes a discussion of the data, the methodology and the empirical results. Section IV concludes with some policy implications.

\section{Factors Causing Differential Effects of Monetary Policy}

The monetary transmission mechanism can be defined as the process through which monetary policy decisions are transmitted into changes in economic growth and inflation, see Taylor (1995). In empirical work, monetary policy decisions are 
nowadays modeled as changes in the nominal short-term interest rate controlled by the central bank. ${ }^{1}$ Changes in the short-term interest rate affect a large set of variables, including the real cost of capital, the real exchange rate, income and wealth. These, in turn, affect aggregate demand. Below, I will briefly discuss factors which might be held responsible for a differential regional impact of monetary policy. ${ }^{2}$

A tightening of monetary policy may reduce demand for investment goods and (durable) consumer goods by increasing the real costs of capital of firms and consumers. Taylor (1995) provides a survey of this socalled interest rate channel. Regions may differ in their sensitivity to changes in the real cost of capital, for example due to a different industrial structure.

Apart from the real cost of capital, monetary policy shocks affect other asset prices, such as the exchange rate. Through the exchange rate channel, monetary policy influences competitiveness and net exports. Regional effects may arise in the presence of cross-regional variation in openness, see Dornbusch, Favero and Giavazzi (1998). A third channel is the equity channel of monetary transmission. It works either through Tobins $q$ theory of investment demand or through a wealth effect on consumer demand, see Mishkin (1996). Regional differences in either Tobins $q$ or in the distribution of wealth may cause regional effects.

A recent theory of monetary transmission focuses on the role of information problems in credit markets. This so-called credit view identifies two transmission channels: the bank lending channel and the balance sheet channel. The former channel looks at the ability and willingness of banks to provide loans, see Kashyap and Stein (1997). Monetary policy affects the economy through the supply of bank credit, as some borrowers (such as small firms) lack substitutes for bank loans. Regional differential effects arise when regions differ in the dependence on and availability of bank credit. The balance-sheet channel of monetary transmission works through the net worth and cash flows of firms. An expansionary monetary policy will raise both, thereby reducing asymmetrical information problems in credit markets. As a result, lending and investment spending may increase. The balance-sheet channel can also explain changes in consumer spending, see

\footnotetext{
${ }^{1}$ See Leeper, Sims and Zha (1996). An alternative measure would be money supply growth, but most central banks have abandoned monetary targeting due to money demand instabilities.

${ }^{2}$ For a comprehensive overview of the literature on the monetary transmission mechanism, see the surveys by Bernanke and Gertler (1995), Cecchetti (1995), Christiano, Eichenbaum and Evans (1998), Gertler (1988), Gertler and Gilchrist (1993) and Mishkin (1995, 1996).
} 
Mishkin (1978). In the credit view, differential regional effects of monetary policy may be caused by cross-regional differences in financial structure, measured by e.g. the proportion of small banks and small firms in an economy, the health of the banking sector, the availability of non-bank funding and the amount of collateral, see Kashyap and Stein (1997) and Dornbusch, Favero and Giavazzi (1998). Other contributions to the literature on the credit channel in Europe are Borio (1996), De Bondt (1998), Favero, Giavazzi and Flabbi (1999), MacLennan, Muellbauer and Stephens (1998) and Mojon (1999b).

The speed of interest rate adjustment also matters. Though not a separate channel, the speed of adjustment will determine how fast a change in interest rates will work its way through the transmission channels. For Europe, many studies have identified large cross-country differences in the adjustability of interest rates, see Borio (1996), Barran, Coudert and Mojon (1997), Kashyap (1997), De Bondt (1998) and Mojon (1999a). Ceteris paribus, the impact of monetary policy shocks will be stronger in countries or regions where the interest rates on debt contracts adjust more rapidly to monetary tightening by the central bank.

All transmission channels described above relate to the effect of monetary policy on aggregate demand. The final effect on output and prices is the result of the interaction of supply and demand. Differential effects of monetary policy could therefore also be the result of regional differences in the supply curve, caused by e.g. differences in the flexibility and institutional features of labor and product markets, see OECD (1999) and De Grauwe (2000).

Empirical work by Carlino and DeFina (1998), Ganley and Salmon (1997) and Hayo and Uhlenbrock (2000) has shown that differential regional effects of monetary policy inside respectively the US, the UK and Germany, can be explained by regional differences in industrial composition. Economic activities differ with regard to their cyclical nature. For example, highly leveraged manufacturing companies will be more sensitive to changes in the real cost of capital, in international competitiveness and in bank credit constraints than government services like health care or education. Industrial composition is thus a useful measure to explain differential effects of monetary policy, though one should be careful not to associate it exclusively with one of the transmission channels described above.

\section{Empirical Evidence}

The empirical approach consists of two steps. First, the regional effects of 
Table 1. Regional Classification

\begin{tabular}{|c|c|c|c|}
\hline Code & Region & Code & Region \\
\hline Belgium & & Greece & \\
\hline BE1 & Reg. Bruxelles-Cap. & GR1 & Voreia Ellada \\
\hline BE2 & Vlaams Gewest & GR2 & Kentriki Ellada \\
\hline \multirow[t]{2}{*}{ BE3 } & Région Wallonne & GR3 & Attiki \\
\hline & & GR4 & Nisia Aigaiou, Kriti \\
\hline \multicolumn{4}{|l|}{ Germany } \\
\hline DE1 & Baden-Württemberg & Italy & \\
\hline DE2 & Bayern & IT1 & Nord Ouest \\
\hline DE3 & Bremen & IT2 & Lombardia \\
\hline DE4 & Hamburg & IT3 & Nord Est \\
\hline DE5 & Hessen & IT4 & Emilia-Romagna \\
\hline DE6 & Niedersachsen & IT5 & Centro \\
\hline DE7 & Nordrhein-Westfalen & IT6 & Lazio \\
\hline DE8 & Rheinland-Pfalz & IT7 & Abruzzo-Molise \\
\hline DE9 & Saarland & IT8 & Campania \\
\hline \multirow[t]{3}{*}{ DE10 } & Schleswig-Holstein & IT9 & Sud \\
\hline & & IT10 & Sicilia \\
\hline & & IT11 & Sardegna \\
\hline \multicolumn{4}{|l|}{ Spain } \\
\hline ES1 & Noroeste & & \\
\hline ES2 & Noreste & Netherlands & \\
\hline ES3 & Madrid & NL1 & Noord-Nederland \\
\hline ES4 & Centro & NL2 & West-Nederland \\
\hline ES5 & Este & NL3 & Noord-Holland \\
\hline ES6 & Sur & NL4 & Zuid-Nederland \\
\hline \multirow[t]{2}{*}{ ES7 } & Canarias & & \\
\hline & & United Kingdom & \\
\hline France & & UK1 & North \\
\hline FR1 & Ile de France & UK2 & Yorkshire/Humberside \\
\hline FR2 & Bassin Parisien & UK3 & East Midlands \\
\hline FR3 & Nord-Pas-de-Calais & UK4 & East Anglia \\
\hline FR4 & Est & UK5 & South East \\
\hline FR5 & Ouest & UK6 & South West \\
\hline FR6 & Sud-Ouest & UK7 & West Midlands \\
\hline FR7 & Centre-Est & UK8 & North West \\
\hline \multirow[t]{3}{*}{ FR8 } & Méditerranée & UK9 & Wales \\
\hline & & UK10 & Scotland \\
\hline & & UK11 & Northern Ireland \\
\hline
\end{tabular}

monetary policy are estimated using a panel regression of real economic growth on the monetary policy indicator and several control variables. Second, the 
regional effects are related to industrial composition in a cross-section regression.

The regional classification used is Eurostat's NUTS1 classification. Regional GDP data are taken from the economics accounts in Eurostats regional statistics database. The sample consists of 8 EU countries: Belgium, Germany, Spain, France, Greece, Italy, The Netherlands and the United Kingdom. ${ }^{3}$ The sample period runs from 1979 to 1995 , with the exception of Spain and Greece, where the sample starts in 1980. EU countries lacking sub-national data at the NUTS1 level (Denmark, Luxembourg, Sweden and Ireland) were dropped from the sample. Finland, Austria and Portugal were left out because of their short sample size. ${ }^{4}$ This leaves 58 regions which are listed in Table 1.

\section{A. The First Step: Panel Evidence}

The dependent variable in the panel regressions is regional real economic growth. Eurostat's GDP data are in Ecu's. They have been converted into real GDP by first converting the data into national currencies and next deflating the resulting series by the national price indices (CPI). The end result is an annual series for real GDP growth $(\Delta y)$.

The panel model uses four explanatory variables. First, following Carlino and DeFina (1998), Ganley and Salmon (1997) and Hayo and Uhlenbrock (2000), the nominal short-term interest rate $(i)$ - measured by the call money rate (line 60B IFS) - is used as our indicator of the monetary policy stance. This approach implies that we estimate the link between the monetary policy instrument and output without explicitly modeling the transmission channels discussed in section II. Thus the monetary transmission process remains a black box.

The remaining three explanatory variables are used to control for other macroeconomic factors. First, the lagged growth rate $\left(\Delta y_{t-1}\right)$ is used to pick up autocorrelation in the real growth series. The second control variable is the inflation rate $(\pi)$. Third, the OECD's general government structural deficit $(d)$ is used as a

\footnotetext{
${ }^{3}$ The sample period was considered too short for the East German states of Brandenburg, MecklenburgVorpommern, Sachsen, Sachsen-Anhalt and Thüringen, where the sample starts in 1992. Berlin was left out because of the distortionary effect of German unification; the French overseas departments (Départments dOutre-Mer) were left out because of their non-European character.

${ }^{4}$ For Finland and Austria, the Eurostat GDP data start in 1988. GDP data for the Portugese regions of Madeira and the Azores start in 1990.

${ }^{5}$ This measure calculates the government deficit as a percentage of potential instead of actual GDP. It is adjusted for the influence of the business cycle and therefore better reflects the stance of fiscal policy than the actual government deficit as a percentage of GDP. The data have been taken from successive issues of the OECD's Economic Outlook.
} 
Table 2. Unit Root Tests

\begin{tabular}{|lllllll|}
\hline & \multicolumn{1}{c}{$i$} & \multicolumn{1}{c}{$\Delta i$} & \multicolumn{1}{c}{$\pi$} & \multicolumn{1}{c}{$\Delta \pi$} & $d$ & \multicolumn{1}{c}{$\Delta d$} \\
\hline Belgium & -2.15 & $-3.70^{* *}$ & -2.07 & $-3.27 * *$ & -1.82 & $-3.96^{* *}$ \\
Germany & $-3.64^{* *}$ & & -2.44 & $-3.49^{* *}$ & -1.92 & -2.53 \\
Spain & -1.77 & $-3.68^{* *}$ & -0.73 & $-3.06^{* *}$ & -1.02 & $-4.70^{* * *}$ \\
France & -2.08 & $-4.29^{* * *}$ & -1.02 & $-3.10^{* *}$ & -1.26 & $-4.72^{* * *}$ \\
Greece & -1.71 & -2.26 & $-3.23^{* *}$ & & -1.97 & $-3.5^{* *}$ \\
Italy & -1.90 & $-3.50^{* *}$ & -1.40 & $-3.99 * * *$ & -0.33 & $-2.82^{*}$ \\
Netherlands & $-2.79^{*}$ & $-4.66^{* * *}$ & -1.75 & $-3.74 * * *$ & -1.98 & $-2.88^{*}$ \\
United Kingdom & -2.44 & $-3.61^{* *}$ & -1.80 & $-3.88^{* * *}$ & -2.21 & $-2.92^{*}$ \\
\hline
\end{tabular}

Note: Augmented Dickey Fuller (ADF) unit root test with 1 lag. *; significant at a $10 \%$ level **; significant at a $5 \%$ level, and ***; significant at a $1 \%$ level.

measure of the fiscal policy stance. ${ }^{5}$ The data on interest rates, inflation rates and deficits are all national.

The unit root tests in Table 2 determine whether the independent variables will enter the panel regressions in levels or in first differences. For most countries, the levels of the interest rate, the inflation rate and the deficit contain a unit root. The exceptions are the German interest rate and the Greek inflation rate. The Augmented Dickey Fuller (ADF) statistic for the German interest rate is -3.65 , which is significant at a $5 \%$ level. For the inflation rate in Greece, the ADF statistic is -3.23 , which is also significant at a $5 \%$ level. In all other countries the ADF statistics for the levels are insignificant at a 5\% level. Therefore, the independent variables will enter the regressions in first differences, with the exception of the German interest rate and the Greek inflation rate.

The data set is not ideal to do an extensive econometric time-series analysis, comparable to e.g. the vector autoregressions of Carlino and DeFina (1998) and Ganley and Salmon (1997). The brief sample period and the low data frequency limit the degrees of freedom. The econometric model is therefore kept simple. For each of the $8 \mathrm{EU}$ countries, the following model was estimated to measure the impact of monetary policy on the regional economies:

$$
\Delta y_{i, t}=\alpha_{i}+\beta_{1, i} \Delta i_{t-1}+\beta_{2} \Delta y_{i, t-1}+\beta_{3} \Delta \pi_{t-1}+\beta_{4} \Delta d_{t-1}
$$

In equation (1), real GDP growth in region $i\left(\Delta y_{i, t}\right)$ is modeled as a function of the lagged change in interest rate $\left(\Delta i_{t-1}\right)$, the lagged growth rate in region $i\left(\Delta y_{i, t-1}\right)$, the lagged change in inflation $\left(\Delta \pi_{t-1}\right)$ and the lagged change in the structural government deficit $\left(\Delta d_{t-1}\right)$. A pooled estimation is conducted using Seemingly Unrelated Regression (SUR). ${ }^{6}$ The pooled estimation allows for fixed effects $\left(\alpha_{i}\right)$. 
Table 3. Panel Regressions Results

\begin{tabular}{|c|c|c|c|c|c|c|c|c|}
\hline \multirow{2}{*}{ Country } & \multirow{2}{*}{ Region } & \multicolumn{2}{|c|}{ Interest Rate } & \multirow{2}{*}{\multicolumn{2}{|c|}{ Statistics }} & \multicolumn{3}{|c|}{ Control Variables } \\
\hline & & $\overline{\text { Coefficient }}$ & t-value & & & Factor & Coefficient & t-value \\
\hline \multirow[t]{4}{*}{ Belgium } & BE1 & -0.52 & 1.92 & $\operatorname{adj} . R^{2}$ & 0.24 & $\Delta y(-1)$ & 0.31 & 2.38 \\
\hline & BE2 & -0.75 & 2.57 & DW & 1.70 & & & \\
\hline & BE3 & -0.33 & 0.98 & \# obs & 45 & & & \\
\hline & & & & Wald & $2.71 *$ & & & \\
\hline \multirow[t]{10}{*}{ Germany } & DE1 & -0.85 & 3.23 & $\operatorname{adj} . R^{2}$ & 0.34 & $\Delta y(-1)$ & 0.23 & 5.87 \\
\hline & DE2 & -0.56 & 2.17 & DW & 2.25 & & & \\
\hline & DE3 & -0.97 & 3.20 & \# obs & 150 & & & \\
\hline & DE4 & -0.68 & 2.40 & Wald & $17.00 * * *$ & & & \\
\hline & DE5 & -0.69 & 2.42 & & & & & \\
\hline & DE6 & -0.61 & 2.53 & & & & & \\
\hline & DE7 & -0.74 & 3.48 & & & & & \\
\hline & DE8 & -0.54 & 2.16 & & & & & \\
\hline & DE9 & -0.68 & 2.73 & & & & & \\
\hline & DE10 & -0.62 & 2.03 & & & & & \\
\hline \multirow[t]{7}{*}{ Spain } & ES1 & 0.57 & 2.01 & $\operatorname{adj} . \mathrm{R}^{2}$ & 0.23 & $\Delta y(-1)$ & 0.25 & 3.01 \\
\hline & ES2 & -0.20 & 1.50 & DW & 1.74 & $\Delta \pi(-1)$ & -0.65 & 2.81 \\
\hline & ES3 & -0.13 & 0.80 & \# obs & 98 & & & \\
\hline & ES4 & 0.24 & 1.74 & Wald & $5.13 * * *$ & & & \\
\hline & ES5 & 0.02 & 0.12 & & & & & \\
\hline & ES6 & 0.03 & 0.11 & & & & & \\
\hline & ES7 & -0.08 & 0.41 & & & & & \\
\hline \multirow[t]{8}{*}{ France } & FR1 & -0.14 & 0.56 & $\operatorname{adj} . R^{2}$ & 0.10 & & & \\
\hline & FR2 & -0.55 & 2.01 & DW & 2.00 & & & \\
\hline & FR3 & -0.63 & 3.27 & \# obs & 128 & & & \\
\hline & FR4 & -0.80 & 3.02 & Wald & $5.58 * * *$ & & & \\
\hline & FR5 & -0.39 & 1.47 & & & & & \\
\hline & FR6 & -0.13 & 0.53 & & & & & \\
\hline & FR7 & -0.29 & 1.21 & & & & & \\
\hline & FR8 & 0.00 & 0.01 & & & & & \\
\hline \multirow[t]{4}{*}{ Greece } & GR1 & -1.34 & 4.28 & $\operatorname{adj} . R^{2}$ & 0.38 & & & \\
\hline & GR2 & -1.07 & 3.88 & DW & 1.68 & & & \\
\hline & GR3 & -0.56 & 2.04 & \# obs & 56 & & & \\
\hline & GR4 & -1.15 & 2.70 & Wald & $2.87 * *$ & & & \\
\hline \multirow[t]{6}{*}{ Italy } & IT1 & -0.71 & 4.13 & adj. $R^{2}$ & 0.26 & $\Delta y(-1)$ & 0.28 & 8.51 \\
\hline & IT2 & -0.67 & 4.29 & DW & 2.08 & $\Delta d(-1)$ & -0.59 & 5.39 \\
\hline & IT3 & -0.82 & 5.51 & \# obs & 165 & $\Delta \pi(-1)$ & 0.27 & 4.03 \\
\hline & IT4 & -0.74 & 4.06 & Wald & $15.43 * * *$ & & & \\
\hline & IT5 & -0.44 & 4.12 & & & & & \\
\hline & IT6 & -0.28 & 1.16 & & & & & \\
\hline
\end{tabular}


Table 3. Continued

\begin{tabular}{|c|c|c|c|c|c|c|c|c|}
\hline \multirow{2}{*}{ Country } & \multirow{2}{*}{ Region } & \multicolumn{2}{|c|}{ Interest Rate } & \multirow{2}{*}{\multicolumn{2}{|c|}{ Statistics }} & \multicolumn{3}{|c|}{ Control Variables } \\
\hline & & Coefficient & t-value & & & Factor & Coefficient & t-value \\
\hline \multirow{9}{*}{ Netherlands } & IT7 & -0.78 & 4.30 & & & & & \\
\hline & IT8 & -0.18 & 0.78 & & & & & \\
\hline & IT9 & -0.72 & 2.47 & & & & & \\
\hline & IT10 & -0.05 & 0.15 & & & & & \\
\hline & IT11 & -0.26 & 0.85 & & & & & \\
\hline & NL1 & -0.71 & 0.76 & $\operatorname{adj} . R^{2}$ & 0.16 & $\Delta y(-1)$ & 0.52 & 4.97 \\
\hline & NL2 & -0.28 & 1.20 & DW & 1.92 & & & \\
\hline & NL3 & -0.47 & 2.37 & \# obs & 60 & & & \\
\hline & NL4 & -0.49 & 1.44 & Wald & 1.17 & & & \\
\hline \multirow{11}{*}{$\begin{array}{l}\text { United } \\
\text { Kingdom }\end{array}$} & UK1 & -0.46 & 2.00 & $\operatorname{adj.} R^{2}$ & 0.34 & $\Delta y(-1)$ & 0.34 & 6.79 \\
\hline & UK2 & -0.44 & 2.09 & DW & 2.01 & $\Delta d(-1)$ & -0.16 & 2.02 \\
\hline & UK3 & -0.56 & 2.86 & \# obs & 165 & & & \\
\hline & UK4 & -0.54 & 2.32 & Wald & $2.07 * * *$ & & & \\
\hline & UK5 & -0.40 & 1.48 & & & & & \\
\hline & UK6 & -0.43 & 2.27 & & & & & \\
\hline & UK7 & -0.61 & 3.28 & & & & & \\
\hline & UK8 & -0.63 & 3.30 & & & & & \\
\hline & UK9 & -0.43 & 1.53 & & & & & \\
\hline & UK10 & -0.24 & 1.26 & & & & & \\
\hline & UK11 & -0.15 & 0.75 & & & & & \\
\hline
\end{tabular}

Note: *; Wald test significant at a $10 \%$ level **; Wald test significant at a 5\% level, and ***; Wald test significant at a $1 \%$ level

Since our objective is to analyze differential regional effects of monetary policy, the coefficients on $\Delta i_{t-1}$ are cross-section specific $\left(\beta_{1, i}\right)$. In order to economize on the use of degrees of freedom, all other coefficients $\left(\beta_{2}, \beta_{3}\right.$ and $\left.\beta_{4}\right)$ are identical across regions.

Table 3 contains the results of the panel regressions. For each country, first the region-specific interest rate coefficients and their t-values are listed, followed by several regression statistics, including a Wald test on the equality of the regionspecific interest rate coefficients. Finally, the coefficients and $t$-values of the control variables $\Delta y_{i, t-1}, \Delta \pi_{t-1}$ and $\Delta d_{t-1}$ are reported. These have been included in the panel regression when significant at a $5 \%$ level.

For 53 out of 58 regions, $\beta_{1, i}$ has the theoretical negative sign, whereby an increase in the interest rate reduces real economic growth. In 34 out of 58 cases, $\beta_{l, i}$ is significant at a $5 \%$ significance level. Spain stands out as the country with 
Table 4. Diagnostic Tests

\begin{tabular}{|c|c|c|c|c|c|c|}
\hline & Jarque-Bera & p-value & Q-stat (2) & p-value & Chow (1988) & p-value \\
\hline BE1 & 0.04 & 0.98 & 3.40 & 0.18 & 1.85 & 0.20 \\
\hline BE2 & 0.49 & 0.78 & 1.08 & 0.58 & 0.88 & 0.44 \\
\hline BE3 & 0.17 & 0.92 & 0.09 & 0.96 & 0.76 & 0.49 \\
\hline DE1 & 0.14 & 0.93 & 1.87 & 0.39 & 0.08 & 0.93 \\
\hline DE2 & 0.45 & 0.80 & 2.22 & 0.33 & 0.02 & 0.98 \\
\hline DE3 & 1.68 & 0.43 & 2.93 & 0.23 & 0.32 & 0.73 \\
\hline DE4 & 1.74 & 0.42 & 1.86 & 0.40 & 0.42 & 0.67 \\
\hline DE5 & 0.32 & 0.85 & 2.62 & 0.27 & 0.10 & 0.91 \\
\hline DE6 & 1.38 & 0.50 & 1.10 & 0.58 & 0.31 & 0.74 \\
\hline DE7 & 0.99 & 0.61 & 3.15 & 0.21 & 0.11 & 0.90 \\
\hline DE8 & 0.15 & 0.93 & 2.13 & 0.35 & 0.18 & 0.84 \\
\hline DE9 & 0.07 & 0.97 & 3.84 & 0.15 & 0.05 & 0.95 \\
\hline DE10 & 0.33 & 0.85 & 1.64 & 0.44 & 0.23 & 0.80 \\
\hline ES1 & 0.03 & 0.98 & 0.33 & 0.85 & 1.68 & 0.23 \\
\hline ES2 & 1.56 & 0.46 & 3.22 & 0.20 & 0.20 & 0.82 \\
\hline ES3 & 0.58 & 0.75 & 3.58 & 0.17 & 0.35 & 0.71 \\
\hline ES4 & 8.74 & $0.01 * * *$ & 0.10 & 0.95 & 0.19 & 0.83 \\
\hline ES5 & 0.31 & 0.86 & 1.23 & 0.54 & 0.06 & 0.94 \\
\hline ES6 & 0.35 & 0.84 & 1.67 & 0.43 & 0.36 & 0.71 \\
\hline ES7 & 0.07 & 0.96 & 1.23 & 0.54 & 6.75 & $0.01 * * *$ \\
\hline FR1 & 1.05 & 0.59 & 2.04 & 0.36 & 0.10 & 0.91 \\
\hline FR2 & 0.65 & 0.72 & 0.04 & 0.98 & 0.03 & 0.97 \\
\hline FR3 & 1.02 & 0.60 & 1.71 & 0.42 & 3.44 & 0.07 \\
\hline FR4 & 0.97 & 0.62 & 4.28 & 0.12 & 0.56 & 0.59 \\
\hline FR5 & 0.48 & 0.78 & 1.58 & 0.45 & 0.11 & 0.90 \\
\hline FR6 & 0.73 & 0.69 & 0.27 & 0.87 & 0.43 & 0.66 \\
\hline FR7 & 3.62 & 0.16 & 2.53 & 0.28 & 0.63 & 0.55 \\
\hline FR8 & 1.52 & 0.47 & 0.38 & 0.83 & 0.00 & 1.00 \\
\hline GR1 & 0.55 & 0.76 & 0.23 & 0.89 & 1.42 & 0.29 \\
\hline GR2 & 0.21 & 0.90 & 1.42 & 0.49 & 2.52 & 0.13 \\
\hline GR3 & 1.18 & 0.55 & 2.04 & 0.36 & 1.00 & 0.40 \\
\hline GR4 & 3.26 & 0.20 & 0.94 & 0.63 & 0.12 & 0.89 \\
\hline IT1 & 0.69 & 0.71 & 1.89 & 0.40 & 1.37 & 0.29 \\
\hline IT2 & 0.29 & 0.87 & 2.57 & 0.28 & 0.67 & 0.53 \\
\hline IT3 & 0.55 & 0.76 & 1.41 & 0.50 & 1.05 & 0.38 \\
\hline $\mathrm{T} 4$ & 1.42 & 0.49 & 1.88 & 0.39 & 0.36 & 0.71 \\
\hline IT5 & 1.21 & 0.55 & 1.17 & 0.56 & 0.51 & 0.61 \\
\hline IT6 & 1.14 & 0.57 & 0.20 & 0.90 & 3.00 & $0.09 *$ \\
\hline IT7 & 0.22 & 0.90 & 1.64 & 0.44 & 1.14 & 0.36 \\
\hline IT8 & 1.17 & 0.56 & 1.97 & 0.37 & 1.24 & 0.33 \\
\hline IT9 & 7.87 & $0.02 * *$ & 1.32 & 0.52 & 0.49 & 0.62 \\
\hline IT10 & 1.74 & 0.42 & 4.55 & 0.11 & 2.05 & 0.18 \\
\hline IT11 & 1.33 & 0.51 & 0.42 & 0.81 & 0.77 & 0.49 \\
\hline
\end{tabular}


Table 4. Continued

\begin{tabular}{|lcccccc|}
\hline & Jarque-Bera & p-value & Q-stat (2) & p-value & Chow (1988) & p-value \\
\hline NL1 & 3.44 & 0.18 & 1.45 & 0.48 & 1.34 & 0.30 \\
NL2 & 0.28 & 0.87 & 0.20 & 0.91 & 0.14 & 0.87 \\
NL3 & 0.54 & 0.76 & 0.89 & 0.64 & 1.51 & 0.26 \\
NL4 & 0.92 & 0.63 & 0.27 & 0.87 & 0.23 & 0.98 \\
UK1 & 1.27 & 0.53 & 4.87 & $0.09^{*}$ & 1.37 & 0.29 \\
UK2 & 0.48 & 0.79 & 0.37 & 0.83 & 1.01 & 0.40 \\
UK3 & 0.17 & 0.92 & 4.84 & $0.09^{*}$ & 3.15 & $0.08^{*}$ \\
UK4 & 2.21 & 0.33 & 3.55 & 0.17 & 1.84 & 0.20 \\
UK5 & 1.38 & 0.50 & 0.18 & 0.91 & 1.70 & 0.23 \\
UK6 & 1.10 & 0.58 & 3.25 & 0.20 & 2.39 & 0.14 \\
UK7 & 1.25 & 0.54 & 3.24 & 0.21 & 1.50 & 0.26 \\
UK8 & 1.41 & 0.50 & 0.85 & 0.66 & 3.88 & 0.14 \\
UK9 & 1.02 & 0.60 & 2.22 & 0.33 & 1.63 & 0.24 \\
UK10 & 0.64 & 0.73 & 4.30 & 0.12 & 0.79 & 0.48 \\
UK11 & 1.32 & 0.52 & 4.63 & $0.10^{*}$ & 0.17 & 0.85 \\
\hline
\end{tabular}

Note: *; significant at a 10\% level **; significant at a 5\% level, and ***; significant at a $1 \%$ level

the worst results for the interest rate coefficients, regarding both their signs and significance. The Wald statistics indicate that in the five largest countries the hypothesis that the $\beta_{1, i}$ 's are identical across regions is rejected at a $1 \%$ significance level. The evidence for differential regional effects is weaker for Greece and Belgium, where the Wald statistic is significant at respectively 5\% and $10 \%$. For the Netherlands, the hypothesis that the $\beta_{1, i}$ 's are identical cannot be rejected even at a $10 \%$ significance level. The finding that the regional variation in the effects of monetary policy is stronger in the larger countries seems plausible. Table 3 also shows that the model fit differs between countries, with France and the Netherlands having the lowest and Germany, Greece and the United Kingdom the highest adjusted $\mathrm{R}^{2}$.

Table 4 reports the results of diagnostic tests on the residuals of the panel regressions. The Jarque-Bera test is used to check for non-normality; the LjungBox Q-statistic tests for residual autocorrelation at lag 2. Finally, Chow's breakpoint test was used to test for a structural break. ${ }^{7}$ The breakpoint was put at

\footnotetext{
${ }^{6}$ In the presence of lagged endogenous variables, the SUR estimates using generalized least squares may not be consistent. However, the results from the SUR estimation do not deviate from the results of ordinary least squares for all regions separately.

${ }^{7}$ The Chow test is applied to the ordinary least squares estimates for the regions separately.
} 
1988, which is in the middle of the sample period. Both the test statistics and their p-values are reported. Out of 174 test statistics, three are significant at a 5\% level. The diagnostic tests therefore do not indicate any serious misspecification.

For countries where the lagged endogenous variable enters the panel regression a distinction can be made between a short-term and a long-term interest rate coefficient. The long-term interest rate coefficient $\left(\beta_{1, i, L T}\right)$ is calculated as $\beta_{1, i} /(1-$ $\beta_{2}$ ). For countries where $\beta_{2}$ does not significantly differ from zero, the long-term coefficient equals the short-term coefficient.

\section{B. The Second Step: Cross-section Evidence}

In the second step I try to explain regional variation in interest rate coefficients. Data limitations make it hard to precisely attribute any differential effects to the factors discussed in section II. For example, regional measures for the bank lending or balance sheet channel are unavailable. Given these limitations I will proceed as follows. First, regional data from Eurostat's community labor force survey are used to measure the importance of industrial composition for monetary transmission. The measure used is the share of the labor force working in industry (LFI) for 1997. The LFI measure has been calculated as the number of people working in industry as a percentage of the total labor force (working in either agriculture, industry or services). This measure differs from the one in Carlino and DeFina (1998), who use the share of manufacturing industry in regional GDP. Second, all factors which are likely to be the same within countries but different between countries - such as institutional features of labor and product markets, the legal system (see Cecchetti (1999)) and presumably also many aspects of financial structure - are captured by country dummy variables.

In the second step, the interest rate coefficients are used in the following crosssection regression:

$$
\beta_{1, i, j}=\gamma+\delta_{1} L F I_{i, j}+\Sigma_{j} \delta_{2, j} d u m_{j}
$$

Equation (2) has been estimated both for the short-term and the long-term interest rate coefficients using their point estimates. ${ }^{8}$ In equation (2), $L F I_{i, j}$ denotes the regional share of the labor force working in industry in region $i$ of country $j$.

\footnotetext{
${ }^{8}$ Some of the estimated interest rate coefficients are close to and insignificantly different from zero. Rather than dropping these observations from the sample or treating them as unobserved, I take the view that regions which are insensitive to monetary policy shocks convey useful information and should be included in a model which is used to explain variation in interest rate sensitiveness.
} 
Table 5. Cross-section Regressions Results

\begin{tabular}{|c|c|c|c|c|c|c|}
\hline \multicolumn{7}{|c|}{ A: Short-term interest rate coefficient } \\
\hline & \multicolumn{2}{|c|}{ EU8 } & \multicolumn{2}{|c|}{ EU4 } & \multicolumn{2}{|c|}{ EMU3 } \\
\hline & coefficient & t-value & coefficient & t-value & coefficient & t-value \\
\hline Constant & -0.11 & 0.64 & 0.11 & 0.68 & 0.13 & 0.72 \\
\hline LFI & -1.79 & 3.60 & -2.47 & 5.16 & -2.54 & 4.64 \\
\hline DUMFR & 0.23 & 2.31 & 0.20 & 2.39 & 0.19 & 2.17 \\
\hline DUMIT & 0.12 & 1.35 & 0.10 & 1.37 & 0.10 & 1.25 \\
\hline DUMUK & 0.18 & 1.96 & 0.15 & 2.06 & & \\
\hline DUMES & 0.68 & 6.53 & & & & \\
\hline DUMBE & 0.00 & 0.01 & & & & \\
\hline DUMNE & 0.03 & 0.22 & & & & \\
\hline DUMGR & -0.55 & 4.04 & & & & \\
\hline Adj. $R^{2}$ & 0.63 & & 0.52 & & 0.55 & \\
\hline \# obs & 58 & & 40 & & 29 & \\
\hline \multicolumn{7}{|c|}{ B: Long-term interest rate coefficient } \\
\hline & \multicolumn{2}{|c|}{ EU8 } & \multicolumn{2}{|c|}{ EU4 } & \multicolumn{2}{|c|}{ EMU3 } \\
\hline & coefficient & t-value & coefficient & t-value & coefficient & t-value \\
\hline Constant & -0.12 & 0.54 & 0.12 & 0.55 & 0.13 & 0.54 \\
\hline LFI & -2.39 & 3.73 & -3.13 & 5.02 & -3.12 & 4.58 \\
\hline DUMFR & 0.41 & 3.12 & 0.37 & 3.43 & 0.37 & 3.28 \\
\hline DUMIT & 0.11 & 0.94 & 0.09 & 0.91 & 0.09 & 0.87 \\
\hline DUMUK & 0.14 & 1.14 & 0.11 & 1.11 & & \\
\hline DUMES & 0.88 & 6.55 & & & & \\
\hline DUMBE & -0.09 & 0.46 & & & & \\
\hline DUMNE & -0.35 & 2.06 & & & & \\
\hline DUMGR & -0.41 & 2.34 & & & & \\
\hline Adj. $R^{2}$ & 0.62 & & 0.55 & & 0.61 & \\
\hline \# obs & 58 & & 40 & & 29 & \\
\hline
\end{tabular}

The hypothesis is that industry is of a more cyclical nature than services or agriculture. As the interest rate coefficients are negative, this translates into the null hypothesis that $\delta_{1}$ has a negative sign. Equation (2) also allows for countryspecific effects through the use of country dummy variables $d u m_{j}$ with coefficients $\delta_{2, j}$. As discussed above, the country dummies may capture all institutional differences between the European countries affecting monetary transmission.

Table 5 contains two sets of cross-section regression results, one for the shortterm interest rate coefficient (panel A) and one for the long-term interest rate coefficient (panel B). Results are reported for the complete cross-section of $8 \mathrm{EU}$ countries (EU8), for the four largest countries (EU4: Germany, France, Italy and the UK) and for the three largest EMU countries (EMU3: Germany, France and 
Table 6. One-way Analysis of Variance

\begin{tabular}{|c|c|c|c|c|c|}
\hline \multicolumn{6}{|c|}{ A: Short-term interest rate coefficient } \\
\hline & Groups & Number & Sum & Mean & Variance \\
\hline $\mathrm{DE}$ & 10 & -6.93 & -0.69 & 0.018 & \\
\hline FR & 8 & -2.92 & -0.37 & 0.078 & \\
\hline IT & 11 & -5.64 & -0.51 & 0.078 & \\
\hline UK & 11 & -4.87 & -0.44 & 0.022 & \\
\hline Source & SS & DF & MS & $\mathrm{F}$ & p-value \\
\hline Between groups & 0.552 & 3 & 0.184 & 3.895 & 0.017 \\
\hline Within groups & 1.701 & 36 & 0.047 & & \\
\hline Total & 1.884 & 39 & & & \\
\hline \multicolumn{6}{|c|}{ B: Short-term interest rate coefficient adjusted for differences in LFI } \\
\hline Groups & Number & Sum & Mean & Variance & \\
\hline $\mathrm{DE}$ & 10 & 1.11 & 0.11 & 0.030 & \\
\hline FR & 8 & 2.47 & 0.31 & 0.025 & \\
\hline IT & 11 & 2.34 & 0.21 & 0.035 & \\
\hline UK & 11 & 2.92 & 0.27 & 0.017 & \\
\hline Source & SS & DF & MS & $\mathrm{F}$ & p-value \\
\hline Between groups & 0.205 & 3 & 0.068 & 2.552 & 0.071 \\
\hline Within groups & 0.966 & 36 & 0.027 & & \\
\hline Total & 1.172 & 39 & & & \\
\hline \multicolumn{6}{|c|}{ C: Long-term interest rate coefficient } \\
\hline Groups & Number & Sum & Mean & Variance & \\
\hline $\mathrm{DE}$ & 10 & -9.00 & -0.90 & 0.030 & \\
\hline FR & 8 & -2.92 & -0.37 & 0.078 & \\
\hline IT & 11 & -7.84 & -0.71 & 0.150 & \\
\hline UK & 11 & -7.39 & -0.67 & 0.050 & \\
\hline Source & SS & $\mathrm{DF}$ & MS & $\mathrm{F}$ & p-value \\
\hline Between groups & 1.289 & 3 & 0.430 & 5.497 & 0.003 \\
\hline Within groups & 2.815 & 36 & 0.078 & & \\
\hline Total & 4.104 & 39 & & & \\
\hline \multicolumn{6}{|c|}{ D: Long-term interest rate coefficient adjusted for differences in LFI } \\
\hline Groups & Number & Sum & Mean & Variance & \\
\hline $\mathrm{DE}$ & 10 & 1.19 & 0.12 & 0.050 & \\
\hline FR & 8 & 3.91 & 0.49 & 0.018 & \\
\hline IT & 11 & 2.28 & 0.21 & 0.068 & \\
\hline UK & 11 & 2.49 & 0.23 & 0.038 & \\
\hline Source & SS & DF & MS & $\mathrm{F}$ & p-value \\
\hline Between groups & 0.654 & 3 & 0.218 & 4.793 & 0.007 \\
\hline Within groups & 1.638 & 36 & 0.045 & & \\
\hline Total & 2.292 & 39 & & & \\
\hline
\end{tabular}


Italy).

The cross-section results show that the coefficient of LFI is both of the right negative sign and significantly different from zero at a 5\% level. This is true for both the short-term and the long-term interest rate coefficients. The dummy coefficients give the size of the country-specific effects after controlling for the effect of LFI, with Germany as the benchmark country (without dummy variable). A positive (negative) coefficient on a country dummy indicates that, after controlling for industrial composition, regions in that country have a less (more) negative interest rate coefficient than regions in the benchmark country and are thus less (more) interest rate sensitive than regions in the benchmark country.

The EU8 estimates for the short-term interest rate coefficients show that the Spanish and French dummy coefficients are positive and significantly different from zero. In contrast, the dummy for Greece is significantly negative. For Belgium, the Netherlands and Italy, the dummy coefficients are close to and insignificantly different from zero at a $10 \%$ level. Between these three countries and Germany, country-specific differences in the monetary transmission mechanism are unlikely to be very important. The United Kingdom is a borderline case with a positive dummy coefficient which is just significant at a $5 \%$ level. Restricting the sample to the EU4 or EMU3 country groupings leads to a more negative and more significant estimate of the LFI coefficient and to only small changes in the estimates of the dummy coefficients. The stronger results for the LFI measure in these sub-samples can be attributed to the exclusion of Spain. As discussed above, the Spanish panel regression yielded bad results.

The results for the long-term interest coefficients, reported in panel B of Table 5 , should be interpreted more cautiously, as the long-term coefficients are affected by sampling uncertainty surrounding both the short-term coefficients and the coefficients on the lagged growth rate. Yet, the significant negative relationship between the interest rate coefficient and the LFI measure remains intact. Comparing panel A to panel B, the differences in the dummy coefficients reflect differences in the estimates of the coefficient of the lagged growth rate in Table 3.

Finally, Table 6 reports the results of a one-way analysis of variance on the interest rate coefficients for Germany, France, Italy and the UK. The aim is to test whether the means of the interest rates coefficients in these four countries are equal. In that case, country-specific differences in monetary transmission would be unimportant. The analysis of variance is done for two sets of interest rate coefficients: the original estimates and the estimates adjusted for differences in 
industrial composition. The adjustment consists of substracting $\delta_{1} L F I_{i, j}$ from each region's interest rate coefficient, with $\delta_{1}$ set equal to -2.47 for the short-term coefficients and to -3.13 for the long-term coefficients, conform Table 5. The purpose of this adjustment is to filter out any cross-country differences due to differences in industrial composition.

Panel A in Table 6 shows that, without controlling for differences in industrial composition, the hypothesis that the means of the short-term interest rates coefficients are equal in these four countries can be rejected at a 5\% significance level. Once we control for differences in the LFI measure, however, the F-statistic drops from 3.90 to 2.55 and the null hypothesis can no longer be rejected at a $5 \%$ level, as panel B shows. Based on this outcome, cross-country differences in monetary transmission do not appear to be very important. This finding corroborates the evidence in BIS (1995), Brittan and Whitley (1997), Dornbusch, Favero and Giavazzi (1998) and Taylor (1995). Note that in contrast to the dummy approach in Table 5, which is used to test for the significance of individual country effects, the analysis of variance boils down to a joint test of the significance of country effects in Germany, France, Italy and the UK.

Panels C and D in Table 6 reveal that for the long-term interest rate coefficients, controlling for industrial composition has a less dramatic impact; the null hypothesis of equal means is rejected at a $1 \%$ significance level both before and after adjustment for differences in LFI. One should bear in mind, however, that the results for the long-term interest rate coefficients are strongly influenced by the zero coefficient on the French lagged growth rate in the panel regression. Given the above-mentioned higher sampling uncertainty surrounding the long-term coefficients, these results are less reliable than the results for the short-term coefficients.

\section{Conclusions and Policy Implications}

An empirical analysis of monetary transmission in 58 European regions leads to the following conclusions. First, within most of the countries analyzed here, there are significant regional differences in the transmission of monetary policy. Relying on cross-country evidence to examine the monetary transmission process in Europe therefore constitutes a simplification and risks overemphasizing the importance of cross-country differences. Second, there appears to be a significant relationship between the regional impact of monetary policy and the proportion of 
the labor force working in industry. This finding supports the US evidence on the importance of industrial composition for monetary transmission. Third, countryspecific dummy variables, which proxy for the more institutionally-determined differences in monetary transmission, are important for Spain, Greece and France.

In contrast, between Germany, Belgium, the Netherlands and Italy, countryspecific differences in the monetary transmission mechanism are unlikely to be very important. Finally, an analysis of variance for Germany, France, Italy and the UK shows that after adjusting for differences in industrial composition, the between-countries variation in the short-term interest rate coefficient is not significantly larger than the within - countries variation.

The regional mix of employment in agriculture, services and industry thus determines the regional transmission of monetary policy. At present, at least the large European countries are well - diversified enough to minimize the risk that ECB policy will produce a markedly different impact across countries. The risk that regional differential effects of monetary transmission give rise to national instability and tensions in the EMU is therefore small, see Gros and Thygesen (1998). This may change, as has been pointed out by Krugman (1993). Increased specialization within an integrated Europe could result in a more heterogeneous industrial structure, as producers flock together to reap the benefits of greater geographic concentration. This could increase the differential regional effects of monetary policy. In contrast, regional differences in transmission which are the result of institutional differences between EU countries - such as cross - country differences in taxation, law, regulation of markets and financial structure - are likely to be further reduced in the process of European integration. Breaking down these institutional barriers will take time, as will the process of industrial specialization. But note that these two developments will have an opposite impact on monetary transmission. Whereas the former will reduce any differential effects of monetary policy, the latter will increase them.

Following the Krugman (1993) argument, suppose that in the future the crosscountry disparities in monetary transmission will increase as a result of industrial specialization. What would the policy implications of such a development be? In most Western countries, the industrial composition results from the free choice of private sector agents, not government planners. Regional effects of monetary policy caused by differences in industry mix are therefore hard to eradicate through direct government intervention. However, governments can try to compensate regions through fiscal policy. The wisdom of such a policy will 
depend on the welfare effects. Economic theory tells us that economic agents who voluntarily take on more risk should be compensated by a higher return. In the context of monetary transmission, one would expect industries which disproportionately suffer from the impact of monetary policy to compensate employers and employees for taking on this risk. For example, job security is higher as a civil servant than as a employee in the car industry, but pay will be less. If there indeed appears to be such a risk-return relationship, the case for fiscal compensation is weak.

When differential regional effects of monetary policy are the result of industrial composition, there is little governments can or should do. However, to the extent that a uniform transmission of ECB policy is still hampered by institutional differences between EMU countries, the first-best solution would be to further harmonize the institutional features of the European economies.

\section{Acknowledgement}

Fred Lee provided excellent research assistance. I am grateful to Casper de Vries and two anonymous referees for very helpful comments on an earlier version.

Date accepted: January 2001

\section{References}

Bank for International Settlements (1995), Financial Structure and the Monetary Policy Transmission Mechanism, Bank for International Settlements, Basle.

Barran, F., V. Coudert and B. Mojon (1997), "The Transmission of Monetary Policy in European Countries", in: S. Collignon (ed.), European Monetary Policy, Pinter, London; 81-118.

Bayoumi, T. and B. Eichengreen (1993), "Shocking Aspects of European Monetary Union", in: F. Torres and F. Giavazzi (eds), Adjustment and Growth in the European Monetary Union, Cambridge University Press, Cambridge.

Bernanke, B.S. and M. Gertler (1995), "Inside the Black Box, The Credit Channel of Monetary Policy Transmission", Journal of Economic Perspectives 9, 27-48.

Bini Smaghi, L. and S. Vori (1993), "Rating the EC as an Optimal Currency Area", Temi di Discussione 187, Banca d'Italia, Rome.

Borio, C.E.V. (1996), "Credit Characteristics and the Monetary Policy Transmission

Mechanism in Fourteen Industrial Countries: Facts, Conjectures and Some 
Econometric Evidence,” in: K. Alders, K. Koedijk, C. Kool and C. Winder (eds.), Monetary Policy in a Converging Europe, Kluwer Academic Publishers, Dordrecht; 77-115.

Brittan, E. and J. Whitley (1997), "Comparing the Monetary Transmission Mechanism in France, Germany and the United Kingdom: Some Issues and Results", Bank of England Quarterly Bulletin, May; 152-162.

Carlino G. en R. DeFina (1998), “The Differential Regional Effects of Monetary Policy”, Review of Economics and Statistics 80, 572-587.

Carlino G. en R. DeFina (2000), "Monetary Policy and the United States and Regions: Some Implications for European Monetary Union", in: J. von Hagen en C. Waller (eds.), Regional Aspects of Monetary Policy in Europe, Kluwer Academic Publishers, Dordrecht, 45-68.

Cecchetti, S.G. (1995), "Distinguishing Theories of the Monetary Transmission Mechanism", Federal Reserve Bank of St. Louis Review 77, 83-97.

Cecchetti, S.G. (1999), "Legal Structure, Financial Structure, and the Monetary Policy Transmission Mechanism”, Federal Reserve Bank of New York Economic Policy Review 5, 9-28.

Christiano, L.J., M. Eichenbaum and C.L. Evans (1998), "Monetary Policy Shocks: What Have We Learned and to What End?", NBER Working Paper 6400.

De Bondt, G.J. (1998), "Credit and Asymmetric Effects of Monetary Policy in Six EU Countries: an Overview", DNB Staff Reports 23, De Nederlandsche Bank, Amsterdam.

De Grauwe, P. and W. Vanhaverbeke (1991), "Is Europe and Optimal Currency Area? Evidence from Regional Data", CEPR Discussion Paper 555.

De Grauwe, P. (2000), Economics of Monetary Union, Oxford University Press, Oxford.

De Nardis, S., A. Goglio and M. Malgarini (1996), "Regional Specialization and Shocks in Europe: Some Evidence from Regional Data", Weltwirtschaftliches Archiv 132, 197-214.

Dornbusch, R., C. Favero and F. Giavazzi (1998), "Immediate Challenges for the ECB", Economic Policy April, 17-63.

Ehrmann, M. (1998), "Will EMU Generate Asymmetry? Comparing Monetary Policy Transmission Across European Countries", EUI Working Paper ECO No. 98/28, European University Institute.

Eijffinger, S.C.W. and J. de Haan (2000), European Monetary and Fiscal Policy, Oxford University Press, Oxford.

Favero, C. and F. Giavazzi (1999), An Evaluation of Monetary Policy Transmission in the Context of the European Central Bank, A Report to the European Parliament.

Favero, C., F. Giavazzi and L. Flabbi (1999), "The Transmission Mechanism of Monetary Policy in Europe: Evidence from Banks Balance Sheets", NBER Working Paper 7231. Ganley, J. and C. Salmon (1997), "The Industrial Impact of Monetary Policy Shocks; Some Stylised Facts", Bank of England Working Paper 68.

Gerlach, S. and F. Smets (1998), "The Monetary Transmission: Evidence from G-7 
Countries", CEPR Discussion Paper 1219.

Gertler, M. (1988), "Financial Structure and Aggregate Economic Activity: An Overview", Journal of Money, Credit and Banking 95, 559-588.

Gertler, M. and S. Gilchrist (1993), "The Role of Credit Market Imperfections in the Monetary Transmission Mechanism: Arguments and Evidence", Scandinavian Journal of Economics 95, 43-65.

Gros, D. and N. Thygesen (1998), European Monetary Integration: From the European Monetary System to European Monetary Union, Addison Wesley Longman, London and New York.

Hayo, B., and B. Uhlenbrock (2000), "Sectoral Effects of Monetary Policy in Germany", in: J. von Hagen en C. Waller (eds.), Regional Aspects of Monetary Policy in Europe, Kluwer Academic Publishers, Dordrecht, 127-158.

Hughes Hallett, A.J. and L. Piscitelli (1999), "EMU in Reality: The Effect of a Common Monetary Policy on Economies with Different Transmission Mechanisms", CEPR Discussion Paper 2068.

Hughes Hallett, A.J., L. Piscitelli and T. Warmedinger (2000), "On the Asymmetric Impacts of a Common Monetary Policy", in: J. von Hagen en C. Waller (eds.), Regional Aspects of Monetary Policy in Europe, Kluwer Academic Publishers, Dordrecht, 89-126.

Kashyap, A.K. (1997), “The Lending Channel and European Monetary Union”, in: S. Collignon (ed.), European Monetary Policy, Pinter, London, 42-76.

Kashyap, A.K. and J.C. Stein (1997), The Role of Banks in Monetary Policy: a Survey with Implications for European Monetary Union, Economic Perspectives, A Review from the Federal Reserve Bank of Chicago September/October, 2-18.

Kieler, M. and T. Saarenheimo (1998), "Differences in Monetary Policy Transmission? A Case not Closed", mimeo.

Krugman, P. (1993), "Lessons of Massachusetts for EMU”, in: F. Torres and F. Giavazzi (eds), Adjustment and Growth in the European Monetary Union, Cambridge University Press, Cambridge, 241-261.

Leeper, E.M., C.A. Sims and T. Zha (1996), What Does Monetary Policy Do?, Brookings Papers on Economic Activity 2, 1-78.

MacLennan, D., J. Muellbauer and M. Stephens (1998), "Asymmetries in Housing and Financial Market Institutions and EMU”, Oxford Review of Economic Policy 14, 5484.

Mishkin, F. (1978), “The Household Balance Sheet and the Great Depression”, Journal of Economic History 38, 918-937.

Mishkin, F. (1995), "Symposium on the Monetary Transmission Mechanism", Journal of Economic Perspectives 9, 3-10.

Mishkin, F. (1996), "The Channels of Monetary Transmission: Lessons for Monetary Policy”, Banque de France Bulletin 27, 33-44.

Mojon, B. (1999a), "Financial Structure and the Interest Channel of Monetary Policy in the euro area”, mimeo, European Central Bank. 
Mojon, B. (1999b), "Credit Channel(s)in the Euro Area: What is the Evidence of Distributional Effects?", mimeo, European Central Bank.

Organisation for Economic Co-operation and Development (1999), EMU, Facts, Challenges and Policies, OECD, Paris.

Ramaswamy, R. and T. Sloek (1997), The Real Effects of Monetary Policy in the European Union: What are the Differences?, IMF Working Paper 97/160.

Taylor, J. (1995), “The Monetary Transmission Mechanism: An Empirical Framework", Journal of Economic Perspectives 9, 11-26. 